\title{
Kimberlitic melt in the carbonate volcanism of Calatrava, central Spain.
}

\author{
K. Bailey ${ }^{1}$ and S. Kearns ${ }^{1}$ \\ ${ }^{1}$ University of Bristol, Department of Earth Sciences, Bristol, BS8 1RJ.
}

Prior to 2004, about 50 isolated cases of carbonate volcanism were known world wide, but then an unforeseen dimension to this activity emerged in central Spain, where extensive carbonate volcanism, was found, constituting the first known case.

Volcanism was first recognised in central Spain in 1836 around Calatrava (180 km south of Madrid). Late Tertiary-Quaternary volcanism here pierces the uplifted Hercynian massif of central Spain, The province is alkaline mafic-ultramafic, 250 vents in $2600 \mathrm{~km}^{2}$, mainly maars and mono-genetic scoria cones, with melilitite the most abundant eruptive, especially in the later stages of activity (Pliocene-Pleistocene, 4-1.5 Ma).

All volcanoes examined so far $(>40)$ have erupted carbonate in a variety of forms, and carry mantle peridotite debris, the terrain being commonly strewn with hornblende megacrysts. Immense quantities of mantle debris have been erupted from maars. Fresh silicate glassy lapilli are present in all forms of eruption, and typically contain globules of immiscible carbonate. Mixed scoria/carbonate, and carbonate layers in the maar deposits are similar to eruptions from the cinder cones: these scoria cones pass into carbonate-supported tuff and agglomerate (also with mantle debris). Sheets of carbonate rich tuffs are spread widely away from the emission centres, and constitute the most abundant effusive carbonate, Eruptions composed largely of carbonate are typically lapilli tuffs,

The first volcanic carbonate was discovered in the Almagro area (Bailey et al, 2005) where maars constitute $\sim 50 \%$ of the volcanic edifices. Their diameters range between $0.5-2 \mathrm{~km}$, averaging $1.1 \mathrm{~km}$. They are frequently compound or nested. One of the finest examples is that of La Nava, $11 \mathrm{~km} \mathrm{SW}$ of Almagro. This is large maar with spectacular layered rim breccias composed of mantle and crust debris in an abundant carbonate matrix.

\section{Maar rim debris flows at La Nava}

In the field these present a well-bedded sequence (with some dunes) comprising layers of great variety in terms of thickness, fragment contents and sizes. Carbonate is dispersed all through the rock matrix, and is the chief constituent in some layers, where the grains are matrix supported. Some layers are largely composed of fragmented country rocks (dominantly quartzite), others are rich in mantle debris, ranging from peridotite to glimmerite, and phlogopite and hornblende megacrysts.

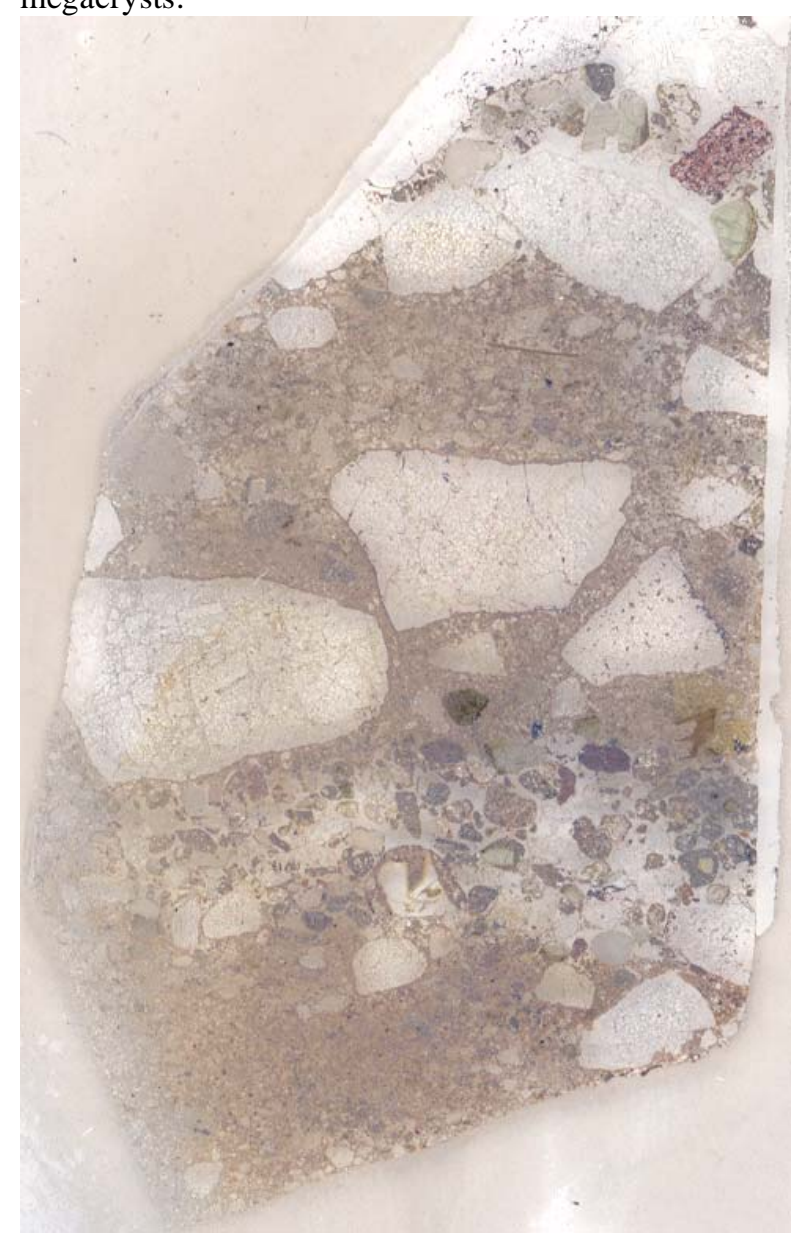

Fig.1 Thin section of maar debris flow showing alternate bands rich in carbonate (pale) and darker layers with quartzite fragments in polverised rock paste. Melt lapilli are concentrated in the pale bands such as that in the lower portion. Width: $2 \mathrm{~cm}$. 
Different fragment types tend to be concentrated in separate eruption layers. Melt lapilli and lava fragments are noticeably concentrated in carbonate rich layers (Fig.1). The whole sequence is clearly the product of many maar eruption pulses of different energies, carrying different fragment loads, some full of near-surface country rocks, and others with debris from a variety of mantle sources. Melts, including carbonate, are samples from greatest depth because they enclose mantle debris, i.e. from below the fragmentation level in the lithosphere (carbonate dissociation boundary). Less common are lapilli enclosing small chips of quartzite, showing that some melts were still molten at high levels. Where these have a carboate matrix it signifies that carbonate melt reached high levels in the vent.

No sign of air-fall deposition has yet been found. Around the maars, the signs are that the bedded deposits were formed by surges of ground-hugging fluidised flows over the maar lip. This is consistent with the observed distribution pattern, where later debris flows exploit low sectors and breaches in the existing ring. Overflow of the rim would also better accord with an upward-, and outward-flaring vent, depositing a wide range of materials from carbonate tuff to breccias (with large, high density mantle fragments). Similar high loads of mantle debris are typical of kimberlite vents, which have a comparable profile.

Layering is also evident on the finest scale in thin (millimetric) sheets, with matrices ranging from pulverised country rock to carbonate, the latter being richest in melt lapilli and mantle debris (Fig.1).

Heterogeneity persists into the microscopic layers, where those rich in country rock have, in addition to quartzite, many types of fine grained sedimentary chunks, and pulverised mud-rock may be a major matrix constituent (Fig.1). Mantle debris is also varied, e.g. clinopyroxene xenocrysts are wide-ranging in colour and composition. Melt lapilli are so varied in matrices and phenocrysts (types and abundances) that finding two the same can be difficult: all out-range the reported lava compositions for Calatrava. Most fragments and lapilli are rounded: angularity is uncommon except for some coarse crystals from late disintegregation of mantle xenoliths. Even large fragments of quartzite (picked up late) are rounded, and hornblende megacrysts are markedly ablated.

Mixing in a steady-state fluidised system (expanded bed) in the vent column, interrupted by intermittent bursts of effusion, is indicated for this immensely complex assemblage of variegated layering and layer mixes.

This is the petrographic context in which there are melt fragments akin to kimberlite. These form a range, where the chief distinction shows in the matrices, with every gradation between carbonate to silicate rich (Fig.2).

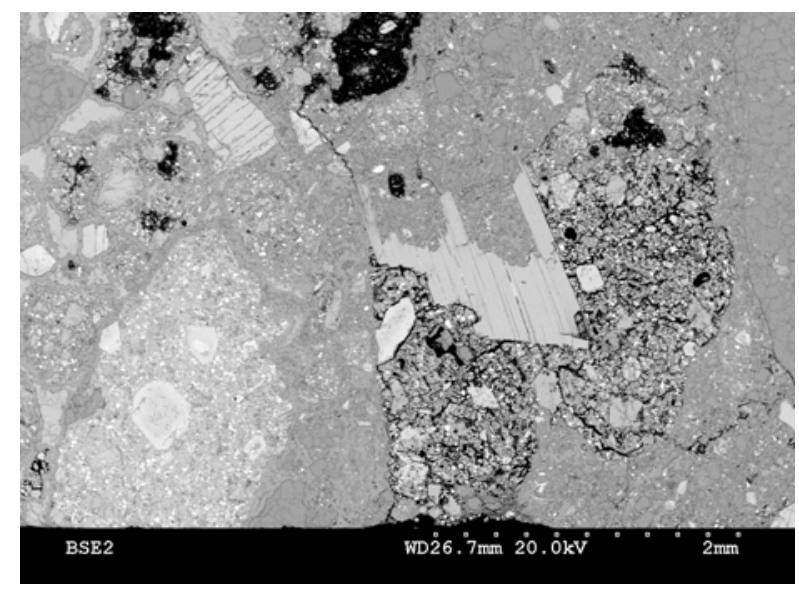

Fig. 2 BSE image of 2 lapilli spanning the range of matrix compositions from carbonate (pale, lower left) to silicate rich (right, with phlogopite xenocryst).

Common factors are in the enclosed minerals such as groundmass clinopyroxene, spinel, perovskite, and melilite, and xenocryst clinopyroxenes and olivines (with variations in proportions) Calcite phenocrysts, calcite-olivine intergrowths, calcite globules and P-rich globules are present in many melt lapilli. Large xenocrysts of phlogopite are found in a few lapilli with a silicate matrix (Fig.2). Enclosure of all these different lapilli compositions in the host carbonate rock matrix indicates that they were present in this state in the vent prior to eruption and consolidation.

Silicate matrices are high in $\mathrm{Fe}$ and $\mathrm{Ti}$, and may show various degrees of alteration, but even where no glass remains there are euhedral areas with $\mathrm{K}_{2} \mathrm{O}$ up to $5 \%$.

Key characteristics of the kimberlitic lapilli (including those with carbonate matrices) are the abundance of spinels (with chromite cores, as previously reported from high $\mathrm{T}$ kimberlites), perovskite, and low $\mathrm{Si}$ clinopyroxenes (<35\% $\mathrm{SiO}_{2}$ : Fig.3).

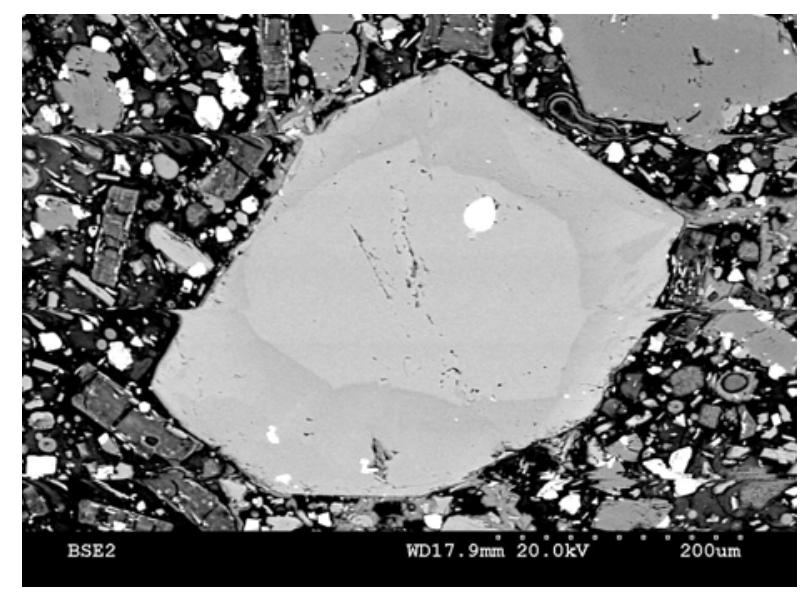

Fig. 3 Clinopyroxene xenocryst with low $\mathrm{SiO}_{2}$ rim in equilibrium with groundmass clinopyroxene. The bright grain in the core (pale) is ulvospinel. Rectangular melilites are seen left.

Low silica activty is also marked by the melilite. Melilitite is the most abundant lava type in Calatrava,, 
and of course, forms the key link between kimberlite and carbonatite, where the intrusive alnoites (:equivalent to melilitite/kimberlite) are a ubiquitous part of the carbonatite association:

Although these melt lapilli might at first suggest a lamproitic affinity, the mineral compositions are not those generally considered characteristic of lamproites, and are closer to those in kimberlite. Phlogopite has Al $\left(\sim 16 \% \mathrm{Al}_{2} \mathrm{O}_{3}\right)$ and $\mathrm{Ti}\left(\sim 6 \% \mathrm{TiO}_{2}\right)$ higher than that in kimberlites generally, and in the range typical of xenolith micas in kamafugites (and associated mica peridotites in Calatrava). In keeping with the low silica activity indicated by perovskite crystallisation, the groundmass clinopyroxene is low in $\mathrm{Si}$, and high in $\mathrm{Al}$ and $\mathrm{Ti}$ : the same composition forms pale brownish rims on clinopyroxene xenocrysts, whereas the cores of these are like those previously reported in Calatrava melilitite (Bailey et al, 2005: $\sim 50 \% \mathrm{SiO}_{2}$, colourless, with inclusions of calcite and glass): see Fig.3.. Olivine xenocrysts may additionally have spinel, clinopyroxene and phlogopite inclusions. In the melt lapilli, the spinel cores are chromite $\left(>35 \% \mathrm{Cr}_{2} \mathrm{O}_{3}\right)$, grading to low $\mathrm{Cr}$ titano-magnetite rims. Calcite, in groundmass and phenocrysts, is in the form of euhedral blades. Overall the rock is high in $\mathrm{Ti}$, as reflected in the clinopyroxene and phlogopite compositions, and the perovskite. Indicated melt source compositions may range through carbonated, phlogopite wehrlite to glimmerite. Melt pressures were high enough to sustain high concentrations of $\mathrm{CO}_{2}$ in the silicate melt, as required for crystallisation of calcite phenocrysts. Melt formation temperature is inferred to be just above the kimberlite solidus, at a depth $\sim 100 \mathrm{~km}$. This melt may represent high velocity eruption of a high pressure heteromorph of the mela-leucitite lavas found elsewhere in the Calatrava province.

\section{References}

Bailey D.K., Garson M., Kearns S. \& Velasco A. P. (2005) Carbonate volcanism in Calatrava, central Spain: a report on the initial findings. Mineralogical Magazine., 69, 907-915. 